\title{
Regional and Local government in Italy: an overview \\ Giulio Vesperini
}

Università degli studi della Tuscia, Viterbo - Italy

\section{Relationships between the State and the territorial collectivities: general features}

\subsection{Regional and local government}

The Italian constitution provides for four types of territorial bodies: regions, provinces, metropolitan cities and towns. The Constitution dedicates all of Title V (Articles 114-133) to them, as well as the first phrase of Article 5, which recognizes and promotes local autonomy. Article 114 considers these territorial bodies together with the State as the constitutive elements of the Republic. Moreover, five regions (Valle D'Aosta, Friuli Venezia Giulia, Trentino Alto Adige, Sicily and Sardinia) together with two autonomous provinces (Trento and Bolzano) are granted of a special legal regime of autonomy..

Further distinctions between the regions may derive from the application of Article 116 of the Constitution. This empowers the State to enact legislation granting further forms of autonomy to interested regions in a number of areas (for example, protection of the environment, ecosystems and the cultural heritage). However, this provision has not yet been implemented.

With regard to the local governmental authorities, the metropolitan cities have not yet been established, despite of the fact that they have been mentioned in the italian legislation since 1990. On the contrary, notwithstanding the continuous legislative efforts to set a limit, the number of provinces and towns has been continuosly increasing, reaching, respectively, the amount of 107 and 8,101,.

Both provinces and towns are wide-ranging categories. About $80 \%$ of the provinces have a population of between 100-500,000 inhabitants; only three provinces, by contrast, have more than $3,000,000$ inhabitants, while two have fewer than 100,000 . As in the past, almost $90 \%$ of the towns still have less than 10,000 inhabitants; just fewer than 10\% have between 10,000 and 60,000; just $1 \%$ has more than 600,000 .

Over time, however, local governments have become more articulated, and new forms have been added to the ones set forth in the Constitution. In particular, the unsuccessful efforts to abolish and merge local governmental authorities has been followed by the establishment of a variety of associational forms. The most important of these bodies are the following: consortia (around 4,000), where different local authorities cooperates in the management of one or more service or in 
the exercise of certain functions; mountain communities (just under 350), established by mountain (and partially mountainous) villages and towns for the development of mountainous zones, and town unions (whose number has grew up to three hundred units), which bring together small towns in order to provide services more efficiently. Each of the associational forms above mentioned has its own basic governing norms (now assembled in the unified text of local government law established by legislative decree n.267/2000), a governing and administrative organization, and a number of financial incentives. A situation that has contributed to the creation of hazardous overlaps for the efficiency (economic and otherwise) of local administration.

In order to complete the picture of local government, it must be mentioned that there was also a reform of the peripheral administration of the State in the late 1990s, in close connection with the reform of decentralization adopted by the Italian legislature (in particular, this is the case of the laws enacted between 1997 and 1999). These laws provided for the transfer of administrative competences from the center to the periphery, effectively prefiguring a comprehensive reform of the organization of ministries and their peripheral offices. According to the reform law of 1999, the prefectures had to be transformed into local branches of the government (uffici territoriali del governo or UTG). These offices were conceived so as to have a general character, in the sense of housing the local offices of all the different national ministries (with the exception of the local offices of the security forces). Anyway the law was never implemented: local offices are still tied to individual national ministries and the UTG (that are now called prefectures-UTG) have a coordinating function, but are not active administrations.

\subsection{The political organization of regional and local bodies.}

Regions, provinces and towns are political entities, empowered therefore to protect the interests of their respective communities. They all have a very similar governmental structure, consisting of three main bodies: the council (consiglio), the giunta and its president (or the mayor in the towns).

The council is the representative body; it exercises law- and policy-making powers; its members are elected by universal suffrage for a five-year term. The giunta is the executive body; it is made up of a number of assessors which may vary (for the local bodies) depending on demographic density. Each of them is assigned to a specific administrative branch as chosen by the chief executive. The president (or mayor) is the chief executive and policy leader. He or she is elected by universal direct suffrage and can exercise a number of powers, such as representation, nomination, designation and administration. 
The main differences between the regions, on the one hand, and provinces and towns on the other, are strictly related with the range of discretionary power which are entitled to exercise.

The Constitution gives to the State the power to determine the political organization of provinces and towns. In this area, the local statutes can dictate only minor rules, and even then, the basic law is currently set forth by the 2000 restatement of local government law.

The law governing regional powers is even more complex. In fact, the regional electoral system and the determination of the electoral qualifications of the president and assessors is an area of concurrent jurisdiction between the region and the State. The form of government, by contrast, can be determined by regional laws and statutes. The Constitution does set forth some default rules that apply until the regional norms have entered into force. It is interesting to observe that the first regions that have legislated in this area after the constitutional reform have substantially conformed to the transition law.

\subsection{Competences: the principles.}

This analysis of the law governing the allocation of competences is divided into two parts. I will focus here on general principles, and then follow with an examination of some specific sectors.

The Constitution sets forth a two-fold principle of separation: separation by subject-matter, which informs the distribution of legislative competences between the State and the regions, subjecting them both to the same limitations, and separation by type of attribution, which tends instead to assign administrative powers to the towns. Regarding the laws, the Constitution enumerates the areas in which the State has exclusive jurisdiction, and those where there is concurrent jurisdiction between the State (within the limits of basic principles) and the regions. All of the areas not included in the two lists are reserved to the regions.

There are two main criteria for determining the areas of exclusive State competence: one criterion assigns exclusive State competence for areas in which are implicated the basic functions of the State (like for example, foreign affairs, defense, public order and security, citizenship, currency, etc.); the other criteria assigns this exclusive competence over areas that are otherwise subjected to regional competence (for example, the determination of the basic levels of civil rights protection and social services that ought to be guaranteed throughout the land, antitrust, the protection of the cultural heritage, general educational norms, etc.).

The list of concurring competences between the State and the regions is very long. It comprehends twenty areas, including large infrastructure projects, job protection and safety, 
harmonization of public accounts and the coordination of public finance and the tax system, communications, public safety, food safety and health protection.

The residual legislative power of the regions is limited to regulating administrative relationships and extends to the main economic sectors (for example, industry, commerce, agriculture), a vast area of personal services (social assistance, academic assistance, professional training, employment policy, etc.), and fundamental parts of land use regulation (for example, transportation, roads, urban planning).

The rules for the separation of legislative powers is also conditioning the allocation of regulatory powers: they belong to the State only in the areas of its exclusive competence, and to the regions in all the other ones. Regulatory powers are also granted to the towns and provinces, in order to let them regulate the organization and exercise of their own functions. In addition to these powers, there are also the statutory powers granted by the Constitution to the regions and (following the 2001 reform) to the provinces and towns to determine the general principles for the organization and function of their respective local bodies.

As mentioned above, the Constitution provides that all administrative functions may be exercised by the towns. But the same norm also establishes that the relative competence can be granted to provinces, metropolitan cities, regions and the State, when this is necessary to guarantee the efficiency and the unity of administrative activity.

It is important to underline that this constitutional norm does not have an immediate prescriptive effect, but it is rather supposed to discipline the decisions of State and regional legislators which effect the distribution of administrative functions. Therefore, the State and regions grant (and govern) the administrative tasks of the local governmental bodies in the exercise of their respective competences. It is, however, up to the State to determine and regulate the "basic functions" of the local entities, no matter which is their area of activity. Finally, the towns and provinces can also autonomously assume additional functions in order to protect the interests of their respective communities.

\section{The main historical events}

Now that the general features of the regional and local governments have been identified, I can illustrate the main events in the history of regional and local government in Italy. This history can be broken down into three separated phases.

The first phase includes the whole period (under the rule of the Albertine Statute, and thus called the "statutory" period) which runs from the unification of the Kingdom of Italy (1861) to the 
fall of Fascism (1943); the second goes from the adoption of the republican Constitution (1948) until the "end of the first Republic" (the late 1980s); the third phase began in 1990 and continued with the adoption of a number of important legislative and constitutional reforms of the regional and local systems of government, and is still in course today.

\subsection{The statutory period}

The first unitary government's attempt to establish regions and decentralize competences failed. Working in the other direction, an 1865 law, informed by centralizing principles, extended the laws of Piedmont to the whole of the newborn Italian kingdom. Later, other laws brought minor correctives to this centralizing model, but did not alter its basic character.

An important development occurred in the late 1880s, with the approval of elections for the offices of mayor and the president of the province, and the significant extension of the right to vote to town and provincial councils. Starting in this period, and continuing over the next thirty years, the local governmental autonomy was greatly reduced: State controls over local decisions multiplied; local governments' decisions concerning the collection and use of revenues were strictly limited; functions previously performed by the towns were taken away by the State; a complicated structure of national technical offices was established to operate in areas of local competence.

The rise of Fascism in 1922 brusquely interrupted the expansion of local entities commenced in the previous thirty years, and undermined the limited democratic reforms of local government previously introduced.

\subsection{The first forty years of the Republic}

The adoption of the republican Constitution of 1948 signaled a significant break with past principles regulating local government: the principle of local autonomy was included as one of the basic principles of the Constitution and refers above all to the ability of local communities to make their own administrative policy, even if different from that of the national government; the regions were established and given legislative and administrative powers in a number of specific areas; radical changes to the system of national administrative controls were foreseen.

However, the statements of principle were not adequately developed in the constitutional text itself, as illustrated by the gap between the very detailed provisions for the regions and the few provisions made for the provinces and towns. Moreover, the constitutional provisions remained completely unimplemented for at least the first fifteen years of the republican period. The only 
significant innovation derived from the further extension of democratic institutions to local governments with the election of local administrators, universal suffrage and political party pluralism.

Only in the 1970s did the system of local government begin to manifest significant changes.

First of all, with the beginning of rule by governments of the center-left, a number of important laws were enacted: the law for the election of regional councils (1968) and the budget law (1970), which empowered the government to transfer administrative functions from the State to the regions in the areas set forth by the Constitution.

Additional but contradictory reforms affected the system of local government.

On the one hand, the range of local governments' responsibilities was enlarged. The norms governing the regions' responsibilities provided, contextually, to assign other responsibilities to local governments. Other norms favoured the use of local governments for choosing the representatives to State deliberative bodies. Still others granted local governments (mainly through their respective representative associations) the right to participate in policy planning hearings held by the central government.

On the other hand, local autonomy was also significantly reduced: the expansion of social welfare led to the growth of central offices and the so-called "parallel administrations"; national public bodies and private actors under public control were given responsibility over local matters in specific territorial areas (the most important examples regard the planning and realization of public projects in large cities and the extraordinary involvement in the South); towns and provinces were saddled with new financial burdens and limitations; the constitutional law on national controls over local governments remained unimplemented, while sectoral laws granted the State and national public bodies powers to intervene at the provincial and municipal level; state financial policies were approved that were discretionary in the total sum and times of distribution, thus limiting local bodies' investment activities.

The twenty years between 1970-1990 mark the period of the most intensive change.

In 1970, in a context shaped by extraordinary social ferment and the first signs of a crisis in the legitimation and efficiency of the political system, the first elections for the councils of the “ordinary-statute” regions took place. These regions then adopted their statutes right afterwards. In the years immediately following (1972 and then 1977), provisions were made for the transfer of functions from the State to the regions.

Then a series of important framework laws were enacted in areas of regional competence (for example, agriculture, health, housing construction, public transportation, etc.). 
The transfer of competences to the regions, however, manifested some important limitations: the powers granted to the regions were “carved” out of the state powers; the regions' legislative autonomy was reduced to a minimum and moreover depended greatly upon transfers from the State; some areas, though constitutionally granted to the regions, were "sucked" up by the European Community; the transfer of competences to local bodies was not met by a corresponding reduction of the central apparatuses of the State.

The local governments also experienced significant changes in this period, which effected their functions, organization, personnel and controls. The sources of local law also changed to include the regions as well as the State, though the weight of the regions turned out to be less than expected. The central State remained basically in control of local administrations (through its control of financing, functions and personnel). It followed that local administrators acted less as local administrative policy-makers and more as intermediaries with the center in search of resources and provisions beneficial to their own constituents.

\subsection{Reforms in the 1990s and the new constitutional law}

The third phase in the history of the evolution of regional and local governments autonomy started in the early 1990s, in the context of a major crisis in the national political and institutional system, and was characterized by a series of very important changes to the constitutional foundation of the local and regional systems.

In 1990, after more than fifty years' wait, the law (n.142/1990) instituting the new system of local autonomy was finally enacted. Between 1990 and 1997, a series of measures increased the financial autonomy of the regions and towns. 1993 laws on the towns and the provinces, and then 1995 and 1999 laws on the regions instituted majoritarian elections for seats on the councils and introduced the principle of the direct election of the head of the respective executives. Other changes affected the regime of controls upon the administration: preventive controls on the legitimacy of administrative acts were greatly reduced, reviews of their merits were abolished and reviews of management and outcomes were introduced. Also very important were the changes in the regime of administrative functions. The most important innovation, provided by law n. 59/1997 and implemented by a series of subsequent legislative decrees (the most important of which was the legislative decree n. 112 of 31 March 1998), grant all administrative functions to the regions and local bodies, except for those expressly reserved to the State. In 2000, as mentioned above, the unified text of the local government law was issued. Between 1999 and 2001, the relevant 
constitutional provisions were amended. First of all, in 1999, the statutory autonomy of the ordinary regions was expanded; then constitutional law n. 3 of 18 October 2001 brought substantial amendments to Title V of the 1948 Constitution.

The main features of the new constitutional law, beyond those already discussed, regard the abolition of preventive controls upon the legislative and administrative acts of the regions and upon the administrative acts of local entities, and the expansion of the financial autonomy of the regions and local governments.

Thus far the constitutional reform has been only partially implemented. Provisions in the area of financial autonomy and those defining the so-called "basic functions" of the towns and provinces have not yet been adopted; the transfer of administrative responsibilities, and the resources necessary to perform them, affected only a small number of state responsibilities, and was then substantially halted in the first years of the current century; the constitutional reform of 2001 was modified by Parliament in 2005, but this change was rejected in the popular referendum of 2006, and did not therefore have any consequence.

\section{Controls upon the regions and local governments}

Having presented the general characteristics of the regional and local governments and the main phases of their historical evolution, I will now examine some key features in the legal system regulating them. I will discuss, in this order, the regime of controls, functions, personnel, financing, citizens' participation and local public services. This analysis enables us to better understand the degree of autonomy enjoyed by the regions and local governments with respect to the State and, more generally, the principles informing the relationships between the local and regional governments and the central government.

As I have mentioned above, the constitutional reform of 2001 abolished the provisions for preventive controls on regional legislation and on the administrative measures of both the regions and local governments. The new constitutional system entrusts the Constitutional Court for the resolution of conflicts between regions and the State to. The Court, however, cannot be accessed by towns or provinces. For this reason, the protection of their prerogatives can be sought indirectly, only if the State or the region chooses to pursue it or a judge, in the course of a trial, raises the question of the constitutionality of a measure arguably injurious to local competences before the Constitutional Court. 
In place of the controls that were abolished, the reform provides for a series of other general controls upon the regions and local governments. The Constitution, for example, allows the national government to preempt regions or local governments when they fail to meet their legal obligations and thus endanger a number of basic values (for example, respect for international norms and treaties or the protection of public safety and security). Most legal commentators hold that this preemptive control regards administrative rather than legislative measures, inertia, rather than the poor or faulty execution of an obligatory measure; in these cases, the government enjoys a wide discretion.

There is instead legislation in place governing management review by the Corte dei conti. The relative controls focus on the fulfillment of the goals set forth in the laws and are summarized by an annual report by the Court to the regional councils, for the regions, and to the Parliament, for local authorities.

Constitutional challenges to these controls were rejected by the Constitutional Court in a 1995 decision. The Court held that "the ultimate purpose of the introduction of management review is to promote the improved performance of the public administration, through the comprehensive evaluation of the economic efficiency of the administrative practice and the efficiency of the services provided." This purpose implicated the regions as well, as they "compete in the administration of most of the individual and public services aimed at meeting social needs.”

The Court also held that the Corte dei conti' review could not extend to the powers of the State, and consequently be seen as counterbalancing regional autonomy. On the contrary, this had to be considered as an essentially collaborative task for the realization of such constitutionally protected principles as the rule of law, impartiality and efficiency.

The most important powers of review still attaching to State offices are instead those of the prefects over local governments to monitor attempts at criminal infiltration into activities for the realization of public works projects or, more generally, to ensure the regular performance of administrative tasks, the national government's standing power to void illegitimate acts by local governments and the commission on local governments' budget and staff for examining the organizational resources and personnel decisions of faltering governments.

State controls on regional and local councils must also be mentioned. With regard to the regional councils, the Constitution provides that the council can be dissolved by a decree of the President of the Republic, in a strictly selected number of cases (acts contrary to the Constitution, serious violations of the law, reasons of national security).

\section{The effective allocation of competences}




\subsection{Introduction}

The basic principles animating the allocation of competences (legislative and administrative) among the State, the regions and local governments have been described above. We must however remember that these principles provide only the general guidelines for the concrete allocation of functions. In fact, in the practice, individual laws (or the Constitutional Court's interpretation of them, especially in the many decisions that have followed the constitutional reform) lead to a different, and sometimes a more complicated allocation of functions.

To illustrate the legal provisions for the allocation of competences, I will examine five specific areas: urban transportation, public support for business, health care and social services, education and research, and housing.

In general, we are in presence of a framework where the competences are fragmented and their applications higly variable. Moreover, the principle of allocation outlined by the constitutional norms tends to favor a commingling of competences. Subsequently, the Constitutional Court has developed the principle of loyal cooperation as the basic principle governing the relationships between the different levels of government; the legislative consequences of this are a great variety of organizational and procedural mechanisms to promote the cooperation of different administrations in their decision-making. It is particularly worth mentioning, among these mechanisms, the recent extension of the mainly consultative competences of the three mixed (so to mean composed by representatives of the State, the regions and local entities) conferences: the Conferenza Stato- regione, the Conferenza Stato-città and the Conferenza Unificata

\subsection{Urban transportation}

The basic law governing the allocation of competences in the area of urban transportation is contained in the legislative decree of 19 November 1997, n. 422.

The State has legislative, policy-making and administrative powers for the protection of international relationships, security interests and the environment. It also demande to define the principles to guide the management and organization of local and regional services.

There are also mechanisms for the coordination of the central/statal and regional policy planning activity: the regions participate in the adoption of the general transportation plan, which is the responsibility of the inter-governmental Committee for economic planning; the Conferenza Stato- regione promotes the coordination of regional planning with State planning; planning 
agreements between the Minister of Transportation, the regions and the interested local governments specify the project to be realized and the means of transportation necessary, in order to achieve a better coordination between national and local systems.

The regions are responsible for planning, policy-making, regulating and financing the entire system of regional and local public transportation. Depending on the case, this involves both projects aimed at implementing or enhancing state projects as well as those requiring further participation of the local governments; this also includes autonomous regional decisions or decisions for which consultations are required, or even joint decisions with local governments and their representatives.

Turning to administrative and management responsibilities, the regions have the power to "require the unitary exercise at the regional level" (for example, with regard to important road services). All other functions of this type are conferred upon the provinces and towns, and must be exercised in conformity with state and regional legislation, and planning and policy decisions: the administrative functions related to road services are generally assigned exclusively to the provinces, and not to the towns; the towns are responsible for the public transportation services that are wholly carried out in their respective territories.

The State has a large number of responsibilities (such as planning, setting standards and technical rules, security controls, policy-making, construction, expansion and management of the national infrastructure) in area public transportation, in addition to the provision of public services (like planning, construction and management of the infrastructure, concession of state property, classification of ports, oversight of private operators). The regions have the duty of regulating, planning, policy-making and carrying out projects affecting the regional infrastructure; the provinces may authorize, oversee and update professional registers and hold examinations. Other powers are assigned by regional and local laws.

The law also governs the mainly procedural mechanisms in place for the coordination of State, regional and local functions.

\subsection{Public support for business}

Towns and provinces exercise a number of powers for the promotion of economic development, support for productive activity, and for plant construction and location.

The powers exercised by local governments in the promotion of economic development include promoting and realizing territorial pacts and "area contracts," as well as those assigned to them by the region. 
Territorial pacts are executed between local governments, other local public bodies, local representatives of interested industries, workers and private actors "for the implementation of public programs in the industrial, agro-industrial, services and tourism sectors” and the promotion of local, environmentally-sustainable, development in the sub-regional area. The rules for the approval of the pacts are determined by the CIPE; these pacts are financed by public and private resources; the National Council for the Economy and Work (CNEL), private entities operating under the auspices of the Ministry of the Economy and the Ministry itself may intervene in the different approval proceedings. Forms of cooperation with regional programs are also envisaged. The region itself is entitled to sign the pact, thus binding itself to implement it; otherwise, the region must be heard by the Minister of the Economy in the course of the approval proceeding and periodically informed about the state of the pact's implementation.

Local governments may assume responsibility for the pact and the granting of the authorizations necessary for the location of the business initiative, the simplification of the formalities necessary for the implementation of the economic initiative and, more generally, the adoption of all of the measures that would be useful for promoting the development of new initiatives.

The "area contract" is legally defined as an "operative instrument executed between local and other administrations, representatives of workers and employers and other potentially interested subjects for the realization of actions aimed at accelerating the development and creation of new jobs" in crisis areas (determined by the government, with the input of Parliament), areas of industrial development in the South and the industrial areas created after the Irpinia earthquake "which manifest the need for a more rapid activation of investments, and availability of equipment and private or public resources.”

Local powers affecting the support of productive activities are essentially the powers to create infrastructure over vast areas for artisan and industrial installments. For the exercise of these powers, local governments set up consortia between themselves, or with other public and private bodies; they receive contributions from the region or the State. The region is in charge for the regulation and all other administrative functions. However, the regional laws implementing legislative decree n.112/1998 assign the functions of planning to the provinces and assign responsibility for the determination, realization, expansion, improvement and management of industrial and ecologically-equipped areas to the towns.

Local governments are also authorized to perform activities in support of business. Such activities were first regulated with reference to small and medium-sized businesses. Then the provinces and towns were also assigned tasks in the concession of "supports, contributions, 
subsidies, incentives and benefits” to industry. It must be mentioned in conclusion that legislative decree n. 112/1998 charged the towns with all of the administrative functions concerning the realization, expansion, cessation and location of productive plants, which had been previously dispersed among many different public administrations.

\subsection{Health Care and Social Services}

Let us analyze social services and health care one at a time.

The basic rules governing social welfare can be found in framework law 8 November 2000, n. 328.

This law both corrects and codifies the contents of numerous preexisting norms (state and regional) regarding individual kinds of social services. Like its predecessors, the law takes the power of managing social services away from the towns and allocates it among different public and private subjects; it grants the State and the regions consistent powers to regulate local services; it does give the towns the powers of regulation, proposal and review of the management carried out by public and private subjects.

The new law, moreover, sets up a complex system of integration among the different public services, and consequently contributes to the creation of a large area of cooperation between the various levels of government and a more circumscribed area in which each level of government has a distinct competence.

The cooperation takes place through a number of different mechanisms. First of all, the State, the regions and local governments all compete for the main powers of governing the social services system (for example, defining the national social services policy, the national fund for social policies, the informational system for the social services, the minimum standards for social services), particularly through the Conferenza unificata. Similar mechanisms for promoting cooperation between the regions and local governments also support the main determinations assumed at the regional level.

In conformity with general principles, the job of administering and providing social services falls to the towns, with some important exceptions. These have to do with both the reservation of particular administrative tasks to the State (such as refugee assistance) and the region's ability to hold on to certain administrative tasks in order to protect the unitary interests of the territory (for example, policy planning for the regional system of social services). Moreover, the towns compete with a plurality of other public and private subjects (for example, public interest organizations and charities) for the right to provide social services. 
The towns' discretion in exercising their actual powers is however circumscribed, both by the law, which specifies particular tasks and the organization and form of their performance, as well as by policy guidelines, mentioned above.

The role of the provinces is mainly to contribute to government policy and to the system's functioning (for example, calling attention to needs for social assistance, running the informational system for social services, planning and management of professional education and training activities for social services providers). In some cases, provinces may receive transfers of administrative power from the regions.

Recent health care reform laws revolutionize the principles for the organization of the national health service, established by the law of 1978.

First of all, they give a predominant role to the regions, which share the responsibility for planning and coordination with the State; they also increase the role of technicians, both in the management of health planning and in the direction of health care facilities, and emphasize the autonomy of the local health units (AUSL) in the provision of health care. Breaking with the past experience, the towns now have a marginal role in health and hospital assistance: their administrative and management powers are limited, and their role is mainly consultative. The responsibilities of the mayor as a local health authority have however remained intact, as well as the towns' responsibility for public hygiene.

The provinces have a consultative role, by virtue of the delimitation of the territorial scope of the local health units; they have the power to approve the location of health clinics as well as other administrative functions granted them by the regions.

The reduction of local governments' administrative and managerial competences following the latest reform has been compensated for, first by regional laws and then by legislative decree $\mathrm{n}$. 229/1999, granting towns the right to participate in planning proceedings, oversight and nominations to the bodies of the main public bodies operating in the health sector. However, the responsibilities in question are often conferred not upon individual local governmental bodies, but upon mixed bodies, made up of representatives of many local bodies or their associations, the regions, the State and interest groups. Some of the most important examples include the understanding that the Conferenza Unificata must stipulate with the government before it can adopt the national health plan, the Conferenza unificata's power to guide the policy of the agency for the regional health services, the competences of the permanent conference for regional health and welfare planning in the adoption of the regional health plan and its implementation.

\subsection{Education and research}


The 2001 constitutional amendments also had a significant effect in the area of education. They actually reinforced the weight of local government and constitutionalized the principle of the autonomy of educational institutions.

The division of legislative competences here is very complex: the State is exclusively responsible for general norms in the area of education. But "education” (presumably meant to address the part of the rules distinct from the general norms) is under the concurrent jurisdiction of the State and the regions. From the administrative standpoint, the responsibilities are distributed between the towns, the schools (which have an autonomous status), the regions and the State (through the central offices of the ministry and the local offices of regional educational authorities). The State determines the general educational goals and the standards that the central institutions are requested to meet; it reviews performance and evaluates the results obtained in the school system; it allocates financial and human resources to educational institutions. The regions are in charge for building activities, educational assistance and permanent assistance, planning for the integrated offering between academic and professional training and the school system, the subdivision of the regional territory and the determination of the academic calendar. The main functions assigned to the local governments regard the establishment, merger and closure of schools, planning the organization of the school systems, planning for the use of buildings and materials. These responsibilities fall to the provinces for high schools, and to the towns for everything else.

Here too there are numerous relationships, connections and interferences between the different levels of government. There may be: a connection between different preceptive measures, attributed to the competence of distinct levels of government, the participation of the unified conference in national-level proceedings, provisions for mixed bodies, made up of representatives of the State, the regions, local governments and educational institutions, numerous forms of agreements and understandings and the participation of local governments in the exercise of regional functions.

The division of competences in the area of higher education and research is relatively simpler. Provinces and towns do not have meaningful competences in this area. The regions are involved in university construction and facilitating the right to study. The other competences are distributed between central offices, universities and research centers (which enjoy a constitutionally protected autonomy).

\subsection{Housing}


After the reforms of the 1990s, the State renounced its previous responsibilities for the planning and the allocation of resources. It is now responsible for the determination of general and unitary principles and purposes, the definition of minimum housing standards and the minimum standards for the quality of public housing; together with the regions and interested local bodies, it develops public housing programs of a national interest; it collects and communicates data on housing conditions; it defines the general criteria for helping lower-income families to access the housing market.

All of the other administrative functions are of regional or local government competence, with a decisive prevalence given to the regions, especially after the first implementation measures of legislative decree n. 112/1998.

The regions are in charge of: the determination of housing policies and objectives, financial planning for the housing sector and financing housing projects, the determination of the kinds of housing to be built and the relative cost limitations, fixing criteria for assigning and managing public housing, the definition of criteria for the selection of those charged with implementing housing programs and the collection, analysis and communication of data concerning the recipients of public contributions and the ownership of public housing facilities.

The towns have few powers and a very limited discretion in exercising them. They may provide for the location of public housing projects, through their zoning rules for low-income housing construction or, in the absence of these, the relevant decisions of the town council: but the zoning rules, and the procedures for their adoption, are tightly regulated by state and regional law; town council decisions have to be adopted within a time period fixed by the region, which may intervene may intervene whenever the towns is unfulfilling the assigned tasks.

The towns implement the plans through specific multi-year programs and through the expropriation of the land included in these programs and the legal transfer of this property for the construction of public housing and related urban and social services. But the law, even in this case, rigorously dictates the contents of the multi-year programs, the recipients of the assigned property, the criteria for determining compensations, the contents of the agreements to be stipulated between towns and their licensees. The towns, moreover, assign the housing and set the relative rents, according to detailed regional rules, and perform a series of other jobs defined by the region, especially in the area of financing, planning and determining the requirements for public housing construction.

\section{The regional and local financing system.}


The Constitution sets forth a unitary discipline for local and regional finance. It provides that the regions, provinces, metropolitan cities and towns shall exercise financial, fiscal and spending autonomy. They shall establish and apply their own tax and revenue policies, in harmony with the Constitution and according to the principles of coordination between public finance and the tax system. The coordination of public finance with the tax system, together with the harmonization of public budgets, is subject to the concurrent legislative jurisdiction of the State and the regions. The regions and local governments also benefit a percentage of the tax payments received by the State, as well as additional resources from the State to promote economic development, social cohesion and solidarity and to counteract economic and social inequalities.

The Constitution also provides that the territories with less taxation potential per inhabitant can receive shares of an equalization fund instituted by State law and whose recipients are discretionary.

A series of measures adopted since the early 1990s had already increased the financial autonomy of the regions and local governments. Laws adopted between 1995 and 2000 instituted new regional taxes and reorganized the transfer of state funds to the regions; they established the principle "of financial and proprietary coverage of the costs sustained in exercising the adminstrative functions conferred" by the State to the regions and local governments; they abolished a series of revenue transfers to the regions and replaced them with an increase of the regional share of the most important of the national taxes; created a national equalizing fund; and they gave regions the chance to participate in the assessment of state tax activities.

State law then established the basic principles and norms for coordinating the regional budgets and accounting. Of these, I would highlight those still in force which require the region to follow a particular method of financial planning and to adopt a multi-year budget, to provide for the possibility of a regional financial law, containing the financial framework for the period included in the multi-year budget and to dictate requirements for regional spending laws, as well as the structure and essential contents of the provisional annual budget, etc.

Furthermore, local and regional finance is subject to the body of norms covering public finance as a whole, and is subject to the central policies and controls established to guarantee the containment of public spending. It is worth highlighting the provisions of a 1998 law which required the regions and local autonomous entities to compete in the reduction of the public deficit (known as the internal stabilization pact), in order to enable Italy to meet its European "growth and stability pact” obligations. The law likewise specifies the actions useful for improving local and 
regional financial balances, defines how respect for the law shall be verified, and provides for sanctions for the failure to reach its objectives.

So far, the success of financial decentralization measures has been only partial. In fact, after the recent reforms, there were no significant changes in the total consolidated public spending directly managed by territorial entities; the percentage of the GNP devoted to local government spending has increased, but so has the share dedicated to the spending of the central administrations as well. The financial autonomy of both the provinces (around 55\%) and the towns (around 77\%) has increased significantly, as has the regions' autonomy over revenues (around 38\%), though to a lesser extent.

\section{Personnel}

The law governing regional and local government personnel presents numerous uncertainties. This area is not expressly addressed by the constitutional law, but is indirectly effected though the constitutional specification of the States's exclusive competence over civil law and social welfare, and the State and the regions' concurrent jurisdiction over workplace safety and the professions. In general, the regions regulate the organization of the regions and local governments, so that they can regulate the employment relationship of regional personnel. The same might be said for local governments: the towns and provinces, in the exercise of their constitutional right to organize and perform their constitutional functions, may be able to regulate certain aspects of their employment practices.

But even here, the limits upon regional and local power are not totally clear, and the Constitutional Court has not provided uniform guidelines. Some decisions hold that the legal and economic status of regional and local personnel is the residual competence of the regions. Thus, in the exercise of this competence, the regions may even enact norms that are different from the national ones.

But other, more recent decisions have distinguished between the (public) regulation of the conditions for accessing regional employment, which is the competence of the regions themselves, and the substantive law governing the public employment relationship, which is governed by private law and is thus part of the State's jurisdiction over civil law.

Similar problems arise for the separation of competences between the political and administrative offices of the regions and local governments. Already in 1993, a State law established that all public administrations (including the regional and local ones) would be governed by a principle of distinction between the policy-making functions, which would be the 
competence of the political offices, and administrative functions, to be carried out by the administrative offices. After the constitutional reform, it seems that the relationship in question is an integral part of the administrative organization and thus falls to the legislative competence of the regions. This however raises the problem of whether the region, in the exercise of its legitimate powers, can derogate from the principle of separation or whether this principle is instead an expression of the constitutional principles of good administration and impartiality, in which case it would limit the regional legislator. The Constitutional Court recently held that the principles of good administration and impartiality demand that regional managers have a right to due process in proceedings for the termination of their employment.

Let us turn now to local government.

The principle of distinction between political and administrative offices is specifically applied to local autonomous bodies by legislative decree $n$. 267/2000, which sets limits upon local statutes and regulations in governing the local management.

It must be added that the management structure of local administrative offices includes two peculiar figures. The first is the traditional figure of the town or provincial secretary. Secretaries are chosen by the town mayor or the president of the province from a specific national register, and provide legal and administrative assistance to the governmental bodies. The second figure, introduced by the 1990 law, is the director-general. Directors-general may be nominated by the mayor (in towns with a population of more than 15,000 inhabitants) and by the president of the province, through a decision of their respective giunta. The term of the director-general's employment is contractually limited, revocable and cannot exceed the term of the mayor or the president of the province. The director implements the policies established by the political organs, according to the directives issued by the mayor or president of the province, and supervises the management of the governmental entity. All of the town or provincial government managers, except for the secretary, must report to the director in exercising their assigned functions.

\section{Public participation}

Regulation of public participation in regional policy-making is the competence of the region itself. Regional statutes and laws are dedicated to this subject. An interesting example is provided by the recent law of Tuscany of December 2007 (n.69/2007). This grants participation rights to resident citizens, non-Tuscans regularly residing in Tuscany, persons working, studying or living in the region and Tuscans living elsewhere when they return to Tuscany. The main participatory institutions are public debates on major projects with significant environmental, territorial, social 
and economic impact, public information, support for other kinds of public participation projects and participation in regional policy- and law-making. A regional authority for the protection and promotion of public participation was also established.

For towns and provinces, a State law recognizes the principle of public participation in local administraton and regulates the main institutions through which the principle itself may be implemented. Local norms complete the picture. In most cases, the law requires local governments to introduce a determinate form of participation and leaves the implementing regulations up to them. But there are also cases in which the law exhausts the regulation of participatory institutions or leaves the decision to implement it up to the local government. The local government then has the option of introducing additional, different participatory institutions than those set forth in the law.

According to the case, participation rights attach to individual citizens, organized groups and associations and local communitites.

The main participatory institutions are the following. First of all, the town is obliged to promote participatory bodies (for example, conferences or forums) and enable them and the associations present on their territory to participate in local administration. Local governments grant associations (and especially civic organizations) a series of rights, such as the right to present demands, petitions and proposals, the right to access public decisions and information, the right to participate in the consultative bodies established by the local government and the right to present complaints in front of the ombudsman. In many cases, the local government also contributes financially to participatory activities, with various types of incentives.

The local government statute must establish the procedures by which interested citizens may participate in administrative proceedings, according to the principles established in the national administrative procedure law of 1990.

The law also provides that the local governments regulate the procedures for the presentation of demands, petitions and proposals by individual or groups of citizens, so as to promote local programs for the better protection of collective interests.

Other important participatory institutions are: the public consultations (for example, meetings between local government representatives and citizens' organizations or groups to discuss a specific problem or a specific solution to it, questionnaires, surveys, samples, opinion polls, etc.), consultative referenda (with the possibility that the local government might distance itself from the outcome) in areas of exclusive local competence and ombudsmen (the establishment of which was left up to the autonomous decisions of the local governments). 


\section{Management of local public services.}

Together with the strictly related administrative competences (for example, granting licenses or concessions, adopting plans, allocating funds, granting certificates, etc.), local governments are traditionally responsible for the provision of a number of services aimed at meeting the basic needs of the community, such as garbage collection, aquaducts, sewers, streetlights, the production and distribution of gas, urban transportation.

Even the regulation of local public services, slowly stratified over the 20th century, has been the object of important reforms in the past fifteen years, aimed above all at implementing European Community principles of competition and at defining the conditions for the private management of public services.

The current law hinges on the distinction (which, however, the law does not further explain) between industrial and non-industrial services.

The basic principles governing industrial services are: the separation between the ownership of networks and facilities and the provision of the service, the contracting of the management of public services to third parties, through public bidding procedures aimed at ensuring the transparency of the selection and the equal treatment of all the aspiring public service providers.

In implementation of the first principle, ownership is reserved to the local government, and service provision to private businesses. When, however, the sectoral laws so provide, it is possible to introduce a further separation, between the ownership of networks and facilities, and their management. The local government retains ownership, even if the law makes an exception allowing it to transfer ownership to a corporation that it effectively controls. The management of networks and facilities may instead be entrusted to a third party: either directly, or through public bidding procedures.

The provision of the service must, however, be entrusted to a private company, chosen in this case as well through public bidding procedures.

The relationships between local governments and the businesses entrusted with public service provision or the management of the networks and facilities must be regulated by specific contracts, called service contracts. These contracts must specify the standard of services to be provided, regulate the methods for verifying respect for these standards, confirm the provider's duty to respect the rules set forth in a services charter in its dealings with its consumers, and its duty to adopt such a charter.

I will examine much more briefly the laws governing non-industrial public services. The general rules essentially address the form of their managment. The provision of the service is 
entrusted directly by the local government (and thus without a competative bidding process), to institutions, special companies, consortia or to private corporations, regulated by the civil code, established by the local governments or in which they have a share. Cultural and leisure activities may be also entrusted to associations and foundations established by local governments, or in which they participate. In consideration of the modest dimensions or the characteristics of the service, direct economic management of the service by the local government may be possible. On the other hand, the local government may use public bidding procedures if there are technical, economic or social reasons for doing so.

\section{Conclusions}

Some quick conclusions can be drawn from the above analysis. The constitutional and legislative reforms of the last decade have created some important tensions in the regional and local systems.

One first tension derives from the multiple relationships between the different components of the national government. At the same time, the autonomy of the regions and local governments has been growing; the tools available to the central government for guiding the periphery are being transformed; the spaces for the cooperation between the regions, local governments and the State are being expanded; an unprecedented number of conflicts between the regions and the State are coming before the Constitutional Court; the much-hyped decentralization has been realized only in part.

Another tension has been created by the resistance of central and local governments to the implementation of the reforms: for the central government institutions, this is demonstrated by the failure of decentralization policies; for the peripheral institutions, this is exemplified by the failure of measures aimed at changing the structure of local power. These resistances hinder innovation, but do not block it altogether: among other things, local governments have found alternative and more flexible forms of aggregation; the decentralization that has been implemented, though much less than that announced, has still significantly altered the functional identity of the regions and local governments in just a few years; the political and administrative organization has experienced important changes.

There is, finally, a tension between the essential features of the constitutional reform and the concrete developments in the local and regional systems. As mentioned above, the constitutional model is based on a two-fold principle of separation: the separation of areas of legislative competences by subject-matter and the separation of the types of administrative functions. The 
constitutional text also regulates some of the mechanisms linking the different levels of government, in pursuit of systemic goals, administrative efficiency and coordination.

But these developments have led to a system that is actually quite different. In extreme synthesis, this is characterized by the existence of a wide area of interference between the different levels of government, and the consequent multiplication of mechanisms for the cooperation between them. And then there is the system of mixed conferences. Constitutional jurisprudence has, among other things: widened the scope for the application of the principle of loyal cooperation, and made it a mechanism for the legitimation of State interference into areas of regional competence and relative compensation, utilized the principle of subsidiarity as a basis for the development of a new form of parallelism between legislative and administrative competences, in which the former now follow the latter and developed the notion of "transversal areas" (for example, antitrust or environmental protection), which are not directly mentioned by the constitutional text, but which lead to a further attenuation of the boundaries between the competences of the State and those of the regions and local governments.

\section{References}

References are only to principal work.

For historical aspects and the evolution of regional and local governments during the second half of XX century, see, M.S. Giannini (eds), I Comuni, Vicenza, Neri Pozza 1967; M.S. Giannini, Il riassetto dei poteri locali in Italia, in Rivista trimestrale di diritto pubbl. 1971, p.451; S. Cassese, Tendenze dei poteri locali in Italia, in S. Cassese, La formazione dello stato amministrativo, Milano, Giuffrè, 1974, p. 331; B. Dente, Il governo locale in Italia, in Il governo locale in Europa, Milano, Edizioni di Comunità, 1977, p. 201; S. Tarrow, Tra centro e periferia. Il ruolo degli amministratori locali in Italia e in Francia, Bologna, Il Mulino, 1977; M. Nigro, Il governo locale. I. Storia e problemi, Roma, Bulzoni, 1980; Istituto per la scienza dell'amministrazione pubblica, Le relaz̧ioni centro-periferia, Milano, Giuffrè, 1984; B. Dente, Governare la frammentazione. Stato, regioni ed enti locali in Italia, Bologna, Il Mulino, 1985; S.Cassese, Centro e periferia in Italia. I grandi tornanti della loro storia, in Rivista trimestrale diritto pubblico, 1986, p. 594; R. Romanelli, Centralismo e autonomie, in R. Romanelli (eds.), Storia dello Stato italiano dall'unità a oggi, Roma, Donzelli, 1995, p. 131; P. Aimo, Stato e poteri locali in Italia. 1848-1995, Roma, Nis, 1997.

The problems faced from the framers of the Constitution are examined by C. Esposito, Autonomie locali e decentramento amministrativo nell'art. 5 della Costiturione, in C. Esposito, La Costiturione italiana. Saggi, Padova, Cedam, 1954.

For the analysis of the main problems in the current law, G. Vesperini,. I poteri locali, I-II, Roma, Donzelli, 1999-2001; G. Berti, G.C. De Martin, Le autonomie territoriali: dalla riforma amministrativa alla 
riforma costituæionale, Milano, Giuffrè, 2001; A. Pajno, L'attuarione del federalismo amministrativo, in le Regioni, 2001, p. 667; G. Berti, G.C. De Martin, Il sistema amministrativo dopo la riforma del titolo V della Costiturione, Roma, Luiss edizioni, 2002; F. Pizzetti, Il nuovo ordinamento italiano tra riforme amministrative e riforme costiturionali, Torino, Giappichelli, 2002; G. Carpani, La conferenza Stato-Regioni. Competenze e modalità di funzionamento dallistituzione ad oggi, il Mulino, Bologna, 2006; V. Lopilato, Le funzioni amministrative, in Il diritto amministrativo dopo le riforme costituzionali. Parte generale, a cura di G. Corso e V. Lopilato, Milano, Giuffrè, 2006, p. 178; F. Marcelli e V. Giammusso, La giurisprudenza costituzionale sulla novella del Titolo V. 5 anni e 500 pronunce, Senato della Repubblica, Quaderni di documentazione del Servizio Studi, n.44, ottobre 2006; La Repubblica delle autonomie nella giurisprudenz̧a costituzionale, A. Pioggia e L. Vandelli (eds.), Bologna, il Mulino, 2007, G. Vesperini, Le autonomie locali nello Stato regionale, in Le regioni, 2007, p. 663. 